\title{
The use of platelet-rich plasma in medicine with particular reference to dentistry and aesthetic medicine
}

\author{
Zastosowanie osocza bogatopłytkowego w medycynie ze szczególnym \\ uwzględnieniem stomatologii i medycyny estetycznej
}

\section{Monika Tysiąc-Miśta ${ }^{1}$, Olaf Gruca', Sylwia Bulanda ${ }^{3}$, Hanna Trzeciak², Magdalena Wyszyńska', Jacek Kasperski}

${ }^{1}$ Katedra Protetyki i Materialoznawstwa Stomatologicznego, Zaklad Materialoznawstwa Stomatologicznego, Śląski Uniwersytet Medyczny w Katowicach, Wydział Lekarski z Oddziałem Lekarsko-Dentystycznym w Zabrzu

Department of Prosthodontics and Dental Materials, Medical University of Silesia, School of Medicine with the Division of Dentistry in Zabrze

Head: prof. dr hab. n. med. Jacek Kasperski

${ }^{2}$ Katedra Protetyki i Materiałoznawstwa Stomatologicznego, Zakład Protetyki Stomatologicznej, Śląski Uniwersytet Medyczny w Katowicach, Wydzial Lekarski z Oddziałem Lekarsko-Dentystycznym w Zabrzu Department of Prosthodontics and Dental Materials, Medical University of Silesia, School of Medicine with the Division of Dentistry in Zabrze

Head: prof. dr hab. n. med. Jacek Kasperski

${ }^{3}$ Studenckie Koło Naukowe, Katedra Protetyki i Materiałoznawstwa Stomatologicznego, Zakład Materiałoznawstwa Stomatologicznego, Śląski Uniwersytet Medyczny w Katowicach, Wydział Lekarski z Oddziałem Lekarsko-Dentystycznym w Zabrzu Head: prof. dr hab. n. med. Jacek Kasperski

KEY WORDS:

platelet rich plasma, aesthetic medicine, aesthetic dentistry

\section{Summary}

Introduction. Autogenous platelet rich plasma (PRP) has found its many applications to medicine, and orthopaedics and aesthetic medicine in particular. It is becoming more and more popular in dentistry. PRP is effectively used as an adjunct in periodontology, implantology, as well as in maxillofacial surgery.

Aim of the study. To present current knowledge on the possibilities of using platelet-rich plasma in medicine, with particular emphasis on aesthetic medicine and dentistry. The authors focused on an approximation of the methods, method of acquiring the preparation, the equipment used
HASŁA INDEKSOWE:

osocze bogatopłytkowe, medycyna estetyczna, stomatologia estetyczna

\section{Streszczenie}

Wprowadzenie. Autogenne osocze bogatophytkowe (PRP) znajduje zastosowanie $w$ wielu dziedzinach medycyny, w szczególności ortopedii i medycynie estetycznej. Ponadto coraz prężniej wkracza $w$ zakres zainteresowań stomatologów. PRP jest skutecznie stosowany jako środek pomocniczy w periodontologii, implantologii, a takze chirurgii szczękowo-twarzowej. Ze względu na obecność licznych czynników wzrostu przyspiesza proces regeneracji i gojenia tkanek, a także poprawia mikrokrażenie. Jest preparatem autogennym, dlatego nie niesie ze soba ryzyka alergii oraz działań niepożadanych. 
and the mechanism of PRP operation.

Methodology. A systematic, comprehensive review of scientific publications published in 2008-2018 in the PubMed database has been carried out and concerned the acquisition and use of platelet-rich plasma in medicine with particular emphasis on aesthetic medicine and dentistry.

Results. Platelet rich plasma contains many biologically active substances that affect cell proliferation and regeneration. Thanks to their properties, it accelerates the reconstruction of tissues, reduces swelling and pain during dental treatment, determines faster osseointegration in surgical treatment, stimulates healing of scars and chronic wounds, also smoothes wrinkles, nourishes and moisturizes the skin.

Conclusions. The range of diseases in which PRP can be administered is very wide. As a method of regenerative therapy, it gives hope on many levels. It is now considered the best and most effective method of non-surgical medicine.

\section{Introduction}

Autologous platelet-rich plasma (PRP) is obtained after collecting and centrifuging patient's peripheral blood. Appropriate centrifugation parameters and separation gel enable the separation of platelets (PLT) suspended in a small amount of plasma from the remaining blood-forming components. A specimen with a very high content of compounds synthesized and released by active thrombocytes is obtained. They are numerous platelet-derived chemotactic factors, which include: fibrinogen, thrombospondin, von Willebrand factors, ADP, ATP, serotonin, $\mathrm{Ca} 2+$, platelet-activating factor (PAF), platelet growth factor (PDGF), platelet
Cel pracy. Celem pracy było przedstawienie aktualnej wiedzy na temat możliwości wykorzystania osocza bogatopłytkowego w medycynie, ze szczególnym uwzględnieniem medycyny estetycznej i stomatologii. Przybliżenie metod, sposobu pozyskiwania preparatu, stosowanego sprzętu oraz mechanizmu działania PRP.

Metodologia. Przeprowadzono systematyczny, kompleksowy przeglad prac naukowych opublikowanych $w$ latach 2008-2018 w bazie danych PubMed na temat pozyskiwania oraz zastosowania osocza bogatopłytkowego w medycynie.

Wyniki. Osocze bogatoptytkowe zawiera wiele biologicznie czynnych substancji wpływajacych na proliferacjęi regeneracji komórek. Dzięki swoim właściwościom przyspiesza odbudowe tkanek, zmniejsza obrzęk i dolegliwości bólowe w trakcie leczenia stomatologicznego, warunkuje uzyskanie szybszej integracji przeszczepu kostnego w leczeniu chirurgicznym, stymuluje gojenie blizn $i$ przewlektych ran, ponadto wygładza zmarszczki, odżywia i nawilża skórę.

Wnioski. Zakres schorzeń, w których można podać PRP jest bardzo szeroki. Jako metoda terapii regeneracyjnej uznana jest obecnie za najskuteczniejsza metodę medycyny niechirurgicznej.

\section{Wprowadzenie}

Autologiczne osocze bogatopłytkowe (PRP - platelet rich plasma) jest preparatem pozyskiwanym po pobraniu i odwirowaniu krwi obwodowej pacjenta. Odpowiednie parametry wirowania oraz żel separujący pozwalają na oddzielenie koncentratu płytek (PLT - platelets) zawieszonych w niewielkiej ilości osocza od pozostałych składników morfotycznych krwi. Otrzymuje się preparat o bardzo wysokiej zawartości związków syntezowanych i uwalnianych przez aktywne trombocyty. Są to liczne płytkopochodne czynniki chemotaktyczne, do których należą: fibrynogen, trombospondyna, czynniki von Willebranda, ADP, ATP, serotoniny, Ca2+, czynnik aktywujący płytki (PAF), 
factor 4 (PF4), b-thromboglobulin (bTG), interleukins (IL-1b and IL-8), ligand CD40 and P-selectins, transforming growth factor (TGF), epidermal growth factor (EGF), insulin-like growth factor (IGF) and vasoendothelial growth factor (VEGF). ${ }^{1,2}$ These substances are signal molecules of the process of tissue reconstruction. It is the essence of the mechanism of action of the platelet-rich plasma that has been used for several years in many fields of medicine.

\section{Aim and methodology of the study}

The aim of the study is to review the relevant literature on the use of platelet-rich plasma in dentistry and aesthetic medicine. A systematic, comprehensive review of scientific publications published in 2008-2018 in the PubMed database has been carried out and concerned the acquisition and use of platelet-rich plasma in medicine with particular emphasis on aesthetic medicine and dentistry.

\section{Methods of obtaining platelet-rich plasma}

Many methods and systems for the separation of platelets to obtain their different concentrations are available on the medical market. $^{2}$ The goal of each method is to reverse the quantitative ratio of erythrocytes to thrombocytes in relation to whole blood. ${ }^{3}$ This is done by means of thrombopheresis, i.e. centrifugation using suitable test-tubes and spinning parameters. ${ }^{4}$ All procedures start with venous blood sampling to a tube containing sodium citrate as an anticoagulant, in a ratio of 1:9. ${ }^{5-7}$ Jensen et al. used EDTA in their studies and noted an increase in the time of tissue regeneration, which was explained by the change of anticoagulant. ${ }^{8}$ The next step is the separation of blood components. Regardless of the set used, after centrifugation three layers are obtained in the tube. The first is the fraction of erythrocytes, the second is platelet-rich plasma, czynnik wzrostu płytek (PDGF), czynnik płytkowy 4 (PF4), b-tromboglobulina (bTG), interleukiny (IL-1b i IL-8), ligand CD40 oraz P-selektyny, transformujący czynnik wzrostu - TGF (Transforming Growth Factor), nabłonkowy czynnik wzrostu - EGF (Epidermal Growth Factor), insulinopodobny czynnik wzrostu - IGF (Insulin-like Growth Factor) oraz czynnik wzrostu śródbłonka naczyń VEGF (Vasoendothelial Growth Factor). ${ }^{1,2}$ Wymienione substancje stanowią cząsteczki sygnałowe procesu odbudowy i gojenia tkanek. Jest to istota działania osocza bogatopłytkowego stosowanego od kilkunastu lat $\mathrm{w}$ wielu dziedzinach medycyny.

\section{Cel i metodyka pracy}

Celem pracy jest przegląd piśmiennictwa w zakresie zastosowania osocza bogatopłytkowego w stomatologii oraz medycynie estetycznej. Przeprowadzono systematyczny, kompleksowy przegląd prac naukowych opublikowanych w latach 2008-2018 w bazie danych PubMed na temat pozyskiwania oraz zastosowania osocza bogatopłytkowego w medycynie ze szczególnym uwzględnieniem stomatologii i medycyny estetycznej.

\section{Metody pozyskiwania osocza bogatopłytkowego}

Na rynku medycznym dostępnych jest wiele metod i systemów separacji płytek krwi, które pozwalają na uzyskanie różnych ich stężeń. ${ }^{2}$ Celem każdej metody jest odwrócenie stosunku ilościowego erytrocytów do trombocytów w odniesieniu do krwi pełnej. ${ }^{3}$ Następuje to na drodze tromboferezy, czyli wirowania przy zastosowaniu odpowiednich probówek oraz parametrów wirowania. ${ }^{4} \mathrm{~W}$ szystkie procedury rozpoczynają się od pobrania krwi żylnej do probówki zawierającej cytrynian so$\mathrm{du}$, jako antykoagulant, $\mathrm{w}$ stosunku ilościowym 1:9.5-7 Jensen i wsp. w swoich badaniach zastosowali EDTA (wersenian potasu) i 
and the third is platelet-poor plasma. ${ }^{3}$ The distribution can be done manually by pipetting or automatically, by the presence of partitions, a special float or separating gel. $3,6,7$ The different time and speed of centrifugation recommended by the manufacturers of individual sets affect the quantitative and qualitative composition of plasma. An important parameter in the thromophoresis is the percentage of platelet recovery, i.e. the number of platelets remaining after separating the remaining fractions from the centrifuged blood as compared to the number contained in the whole blood collected from the patient. ${ }^{4}$ The second important factor to pay attention to during the procedure is the density of the platelets, indicating the amount of plasma in which the obtained platelets are suspended. This parameter allows the adaptation of the best method to the clinical situation. ${ }^{4}$

Depending on the method, PRP can be obtained with thrombocyte concentration over eight times higher than in whole blood. Three basic methods are distinguished:

- single centrifugation - with the use of traditional laboratory centrifuges; after centrifugation, a layer of thrombocytes between the erythrocyte layer and plateletpoor plasma is pipetted,

- double centrifugation - with the use of commercial kits enabling greater thrombocyte concentration by repeated centrifugation of the previously centrifuged plasma,

- selective blood filtration - using special filters that allow separation of erythrocytes from platelet-rich plasma and leukocytes. ${ }^{6}$

Commercial systems make it possible to obtain plasma with up to eleven times higher number of PLT in a millilitre than in whole blood., ${ }^{3,4,9}$ The higher concentration of platelets is associated with a higher content of growth factors, and thus, better quality of the preparation. At the same time, methods increasing thrombocyte concentration increase the concentration of odnotowali wydłużenie czasu gojenia się tkanek, co tłumaczyli zmianą antykoagulantu. ${ }^{8}$ Kolejnym etapem jest separacja składników krwi. Niezależnie od zastosowanego zestawu, po odwirowaniu w probówce otrzymywane są trzy warstwy. Pierwszą stanowi frakcja erytrocytów, drugą osocze bogatopłytkowe, a trzecią osocze ubogopłytkowe. ${ }^{3}$ Rozdział można wykonać ręcznie przez pipetowanie lub automatycznie, dzięki obecności przegród, specjalnego pływaka lub żelu separującego. ${ }^{3,6,7}$ Różny czas i prędkość wirowania zalecane przez producentów zestawów wpływają na skład ilościowy i jakościowy osocza. Istotnym parametrem w tromboferezie jest procent odzysku płytek, czyli liczba płytek uzyskanych po oddzieleniu pozostałych frakcji z odwirowanej krwi w porównaniu do liczby zawartej w pobranej od pacjenta krwi pełnej. ${ }^{4}$ Drugim ważnym współczynnikiem, na który należy zwrócić uwagę podczas wykonywania procedury, jest zagęszczenie płytek, mówiące o ilości osocza, w którym pozyskane płytki są zawieszone. Parametr ten pozwala dostosować najlepszą metodę do potrzeby klinicznej. ${ }^{4}$

W zależności od metody można uzyskać PRP o koncentracji trombocytów ponad 8 razy większej niż we krwi pełnej. Wyróżnia się trzy zasadnicze metody:

- pojedynczego wirowania - z użyciem tradycyjnych laboratoryjnych wirówek; po odwirowaniu odpipetowuje się warstwę trombocytów znajdujących się między warstwą erytrocytów a osoczem ubogopłytkowym,

- podwójnego wirowania - z użyciem komercyjnych zestawów, umożliwiających większą koncentrację trombocytów, przez powtórne wirowanie odwirowanego wcześniej osocza,

- selektywnej filtracji krwi-z użyciem specjalnych filtrów, które umożliwiają oddzielenie erytrocytów od osocza bogatopłytkowego i leukocytów. ${ }^{6}$ 
leukocytes, which release catabolic factors and increase cellular inflammatory response. ${ }^{6,10-12}$ According to some authors, this fact adversely affects the process of regeneration of damaged tissues. ${ }^{1,13}$ However, there are indications of positive action of the rich cell metabolism on the reconstruction of soft tissues, which has been proved by Ciślik-Bielecka et al. ${ }^{7}$

\section{The application of platelet-rich plasma}

Preparations of autologous plateletrich plasma have varied applications in many fields of medicine, such as: maxillofacial surgery, cardiosurgery, orthopaedics, dermatology, sports or aesthetic medicine. ${ }^{1}$ It was first used by Ferrari et al. in 1987 during autologous transfusion in a patient after cardiac surgery. ${ }^{1,14,15}$ The use of autologous thrombocyte and erythrocyte preparations has reduced the need for blood transfusions during surgery and in consequence lowered the cost of the procedure. Later, PRP found a wide application to orthopedics, ophthalmology, dentistry, aesthetic medicine, neurosurgery and regenerative medicine. ${ }^{3}$

\section{Platelet-rich plasma in dentistry}

Platelet-rich plasma is one of regenerative methods used in the treatment of periodontitis. Chronic periodontitis (CP) is a common inflammatory disease that causes damage to the tissues surrounding the teeth. Many treatments have attempted to stop the progression of the disease. Ameer et al. demonstrated the antiinflammatory effects of PRP by monitoring the number of lymphocytes before and after its application to the periodontal pocket. Clinical periodontal factors (PLI, GI, BOP, PPD and RAL) improved after one month of PRP administration. ${ }^{16}$ Rattanasuwan et al. observed that plasma with high platelet concentration stimulated proliferation, migration and attachment of cultured periodontal ligaments. ${ }^{17}$ In addition, PRP can be used in the regeneration
Komercyjne systemy umożliwiają otrzymanie osocza nawet o 11 razy wyższej liczbie PLT w mililitrze niż w krwi pełnej. ${ }^{3,4,9}$ Wyższe stężenie płytek związane jest $\mathrm{z}$ większą zawartością czynników wzrostu, a co za tym idzie, lepszą jakością preparatu. Jednocześnie metody zwiększające koncentrację trombocytów zwiększają stężenie leukocytów, które uwalniają czynniki o działaniu katabolicznym oraz zwiększają komórkową reakcję zapalną ${ }^{6,10-12}$ Według części autorów fakt ten negatywnie wpływa na proces regeneracji uszkodzonych tkanek. ${ }^{1,13}$ Jednak są przesłanki pozytywnego działania bogatoleukocytarnego osocza na odbudowę tkanek miękkich, czego dowiodła Ciślik-Bielecka i wsp. ${ }^{7}$

\section{Zastosowanie osocza bogatoptytkowego}

Preparaty autologicznego osocza bogatopłytkowego wykorzystywane są w wielu dziedzinach medycyny, takich jak: chirurgia twarzowo-szczękowa, kardiochirurgia, ortopedia, dermatologia, medycyna sportowa czy medycyna estetyczna. ${ }^{1}$ Po raz pierwszy zastosowali je Ferrari i wsp. w 1987 roku podczas autologicznej transfuzji u pacjenta po zabiegu kardiochirurgicznym. ${ }^{1,14,15}$ Użycie autologicznych preparatów trombocytarnych i erytrocytarnych zmniejszało zapotrzebowanie na transfuzje krwi podczas operacji i w konsekwencji zmniejszyło koszt procedury. Później PRP znalazło szerokie zastosowanie w ortopedii, okulistyce, stomatologii, medycynie estetycznej, neurochirurgii oraz szeroko pojętej medycynie regeneracyjnej. ${ }^{3}$

\section{Osocze bogatoptytkowe w stomatologii}

Osocze bogatopłytkowe jest jedna z metod regeneracyjnych stosowanych $\mathrm{w}$ leczeniu zapalenia przyzębia. Przewlekłe zapalenie ozębnej (CP) jest częstą chorobą zapalną, która powoduje zniszczenie tkanek otaczających zęby. Ameer i wsp. wykazali przeciwzapalne działanie PRP poprzez monitorowanie liczby 
of immature permanent teeth. When such teeth are fractured or damaged, their crowns are restored, but thin dentine walls can be regenerated using PRP. ${ }^{18}$ Maxillo-facial surgery is a department of dentistry in which platelet-rich plasma is used on a large scale, among others, to accelerate bone regeneration in the implantation of dental prostheses and to obtain a faster implant integration after reconstruction of the jaw bone or paranasal sinuses with autologous bone graft. ${ }^{1,3,19}$ PRP is also administered after tooth extraction for faster regeneration of alveolar tissues. ${ }^{3}$

\section{Platelet-rich plasma in aesthetic medicine}

Many studies have shown that injection with PRP is a promising method of skin rejuvenation, which is why therapies utilizing platelet-rich plasma are an important part of the growing popularity of regenerative medicine. ${ }^{20}$ PRP and fat tissue transplantation were also used in facial reconstructive surgery. After a year of observation, a satisfactory correction of the facial contour was obtained. ${ }^{1,21}$ Alam et al. conducted a randomized study of the impact of PRP on arresting the process of photo-aging of facial skin. The study participants used PRP on one side of the face of and physiological saline on the other. During the first assessment, dermatologists found that the average results of photo-aging did not show a significant difference between PRP and physiological saline in their effect on small wrinkles, discolorations and skin imperfections. However, after 6 months of a single treatment, the participants observed an improvement in those facial regions where PRP was applied. It was noted that the appearance of the skin improved significantly more with a single treatment of PRP than with the use of saline. ${ }^{22}$ Moreover, the anabolic effect of concentrated plasma on fibroblast cells and keratinocytes encourages the use of its preparations to revitalize the skin. Intradermal PRP injections in three sessions showed limfocytów przed i po jego zastosowaniu do kieszonki dziąsłowej. Kliniczne wskaźniki przyzębia (PLI, GI, BOP, PPD i RAL) poprawiły swoją wartość po 1 miesiącu stosowania PRP. ${ }^{16}$ Również Rattanasuwan i wsp. zaobserwowali, że osocze z dużą koncentracją płytek stymulowało proliferację, migrację i przyłączanie hodowanych komórek więzadła przyzębia. ${ }^{17}$ Ponadto PRP stosować można w regeneracji niedojrzałych zębów stałych. Złamane lub uszkodzone niedojrzałe zęby stałe osób w wieku od 6 do 28 lat, które mają odbudowaną koronę, ale cienkie ściany zębiny można zregenerować za pomocą PRP. ${ }^{18}$ Chirurgia twarzowo-szczękowo jest działem stomatologii, w którym osocze bogatopłytkowe stosuje się na szeroką skalę. Wykorzystywane jest do przyspieszenia regeneracji kości w implantacji wszczepów zębowych ${ }^{3}$ oraz w celu uzyskania szybszej integracji przeszczepu w rekonstrukcji kości szczęki lub zatok przynosowych autologicznym przeszczepem kości. ${ }^{1,3,19}$ PRP jest również stosowane po ekstrakcji zęba w celu szybszej regeneracji tkanek zębodołu. ${ }^{3}$

Osocze bogatoptytkowe w medycynie estetycznej

Liczne badania wykazały, iż iniekcja z PRP jest obiecującą metodą odmładzania skóry, dlatego też terapie osoczem bogatopłytkowym są ważną częścią rosnącej popularności medycyny regeneracyjnej. ${ }^{20} \mathrm{~W}$ połączeniu z przeszczepieniem tkanki tłuszczowej PRP stosowano również w chirurgii rekonstrukcyjnej twarzy. Po trwającej rok obserwacji uzyskano zadowalającą korektę konturu twarzy. ${ }^{1,21}$ Alam i wsp. przeprowadzili randomizowane badania wpływu PRP na zatrzymanie procesu fotostarzenia skóry twarzy. Uczestnicy badania stosowali na jedną stronę twarzy PRP, na drugą sól fizjologiczną. Podczas pierwszej oceny dermatolodzy stwierdzili, iż średnie wyniki fotostarzenia nie wykazały znaczącej różnicy między PRP a solą fizjologiczną dla niewielkich zmarszczek, 
satisfactory results in face and neck rejuvenation and scar weakening. ${ }^{23}$ PRP is also used in the treatment of diseases such as acne, eczema, atrophy, hyperpigmentation and vitiligo. ${ }^{24} \mathrm{El}$ Domyati et al. reported an accelerated healing of acne scars and an increase in epidermal thickness after using PRP in combination with dermaroller or trichloroacetic acid at concentration of $15 \%$. Moreover, the skin of the examined persons showed a more ordered structure of collagen fibres and a significantly reduced number of unadapted elastic fibres. ${ }^{25}$ PRP is also applied after surgical face-lifting and blafaroplastic procedures. ${ }^{24}$ It has been shown that adding PRP to face lipofilling reduces the time of regeneration and improves the overall aesthetic effect. ${ }^{26}$

PRP is also used in the treatment of chronic, difficult to heal wounds, such as burns or diabetic foot ulcers. ${ }^{6}$ Local and cyclic administration of platelet-rich plasma (every two weeks) results in statistically faster epithelialisation and closure of the wound, improved sensation and nerve regeneration, and fewer complications compared to standard surgical treatment. 1,24,27,28 Moreover, the combination of standard surgical treatment and platelet-rich plasma therapy will reduce capillary bleeding (elimination of drains), diminish pain and swelling, shorten treatment time. ${ }^{24}$

Highly concentrated PRP was also used in treatment of androgen alopecia (AGA), commonly affecting men and women. The standard treatment of this disease is unsatisfactory. Therefore, Butt et al. used PRP as an alternative option for patients with AGA. The results showed that it is an effective therapy, as indicated by the increase in hair density. ${ }^{29}$

\section{Platelet-rich plasma in orthopaedics}

In orthopaedics, PRPis most often used during the treatment of chronic degenerative damage to tendons and joints, fractures and inflammation of the bone and in pseudoarthrosis. ${ }^{1,3}$ PRP is an przebarwień i niedoskonałości skóry. Jednak po 6 miesiącach od pojedynczego leczenia, uczestnicy zaobserwowali poprawę w obrębie miejsc twarzy, na których aplikowano PRP. Zauważono, że wygląd skóry poprawił się znacznie bardziej przy pojedynczym leczeniu PRP, niż przy użyciu soli fizjologicznej. ${ }^{22}$ Ponadto anaboliczne działanie skoncentrowanego osocza na komórki fibroblastów i keratynocytów skłania do stosowania jego preparatów w celu rewitalizacji skóry. Śródskórne wstrzyknięcia PRP w 3 sesjach wykazały zadowalające wyniki w odmładzaniu twarzy i szyi oraz zmniejszeniu blizny. ${ }^{23}$ PRP wykorzystuje się również podczas leczenia chorób, takich jak: trądzik, egzemy, atrofia, hiperpigmentacja oraz bielactwo. ${ }^{24}$ El-Domyati i wsp. wykazali przyspieszenie gojenia się blizn potrądzikowych oraz wzrost grubości naskórka po zastosowaniu PRP w połączeniu z dermarollerem lub kwasem trichlorooctowym w stężeniu $15 \%$. Co więcej, skóra badanych osób wykazała bardziej uporządkowaną budowę włókien kolagenu oraz znacznie zmniejszoną ilość nieupostaciowanych włókien elastycznych. ${ }^{25}$ PRP aplikuje się również po face-liftingu chirurgicznym oraz zabiegach blafaroplastyki. ${ }^{24}$ Wykazano, iż dodanie PRP do lipofillingu twarzy skraca czas regeneracji i poprawia ogólny efekt estetyczny. ${ }^{26}$

PRP stosowane jest również w leczeniu przewlekłych, trudno gojących się ran, takich jak oparzenia lub owrzodzenia stopy cukrzycowej. ${ }^{6}$ Miejscowe i cykliczne podawanie osocza bogatopłytkowego (co ok. 2 tygodnie) powoduje statystycznie szybszą epitelializację i zamknięcie rany, poprawę uszkodzonego czucia i regenerację nerwów oraz mniejsze powikłania w porównaniu z standardowym leczeniem chirurgicznym. 1,24,27,28 Ponadto skojarzenie klasycznego leczenia chirurgicznego i terapii osoczem bogatopłytkowym redukuje krwawienie włośniczkowe (brak konieczności stosowania drenów), zmniejszenie bólu i obrzęku, krótszy czas rekonwalescencji. ${ }^{24}$

Wysokoskoncentrowane PRP zastosowano 
effective therapeutic method in the treatment of tendinopathy. In the de Vos et al. study, the effects of injection into the Achilles tendon of PRP and physiological saline were compared. ${ }^{1,30}$ Vetrano et al., however, demonstrated an advantage of PRP over ESWT therapy (extracorporeal shock wave therapy) in patients with patellar tendinopathy. 1,31

Anitua et al. showed positive effects of platelet concentrates on tanocytes, proving their effect on the proliferation of these cells and the release of activators of angiogenesis. ${ }^{32}$

Franchini et al. used platelet concentrate in fractures and inflammations, bone reconstructions in hip replacements, pseudoarthrosis, and in fibrous dysplasia. ${ }^{33}$ Bibbo et al. did research on patients undergoing arthrodesis of the ankle. ${ }^{34}$ Further applications include reconstruction of the knee joint and improvement of regeneration of the cruciate ligament grafts. ${ }^{4}$ Attempts are being made to use platelet-rich plasma to treat joint surface damage as well as rheumatoid arthritis. The research aims to accelerate the healing of articular cartilage after administration of PRP. ${ }^{4}$

\section{Limitations of the method}

Many studies document the positive effects of PRP. However, there are publications which report no benefits or little effect. The level of evidence from the available published data is low. There are still no double-blind, randomized studies carried out on a large research group. Many protocols, devices and centrifuges have been developed to obtain various blood products. Unfortunately, all are categorized under one common name of the platelet-rich plasma. Ehrenfest et al. classified and described platelet concentrates depending on the amount of leukocytes and thrombin. ${ }^{35}$ Therefore, doctors who apply PRP should be very cautious during its preparation and use.

The appropriate concentration of platelets proved to be important. Giusti et al. showed that także w powszechnie występującej chorobie kobiet i mężczyzn, łysieniu androgenowym (AGA). Klasyczne leczenie tej choroby jest niezadowalające, dlatego Butt i wsp. zastosowali PRP jako alternatywną opcję dla pacjentów z AGA. Wyniki wykazały, że jest to skuteczna terapia, na co wskazuje zwiększenie gęstości włosów. ${ }^{29}$

\section{Osocze bogatoplytkowe w ortopedii}

Zastosowanie PRP w ortopedii najczęściej występuję podczas leczenia: przewlekłych zwyrodnieniowych uszkodzeń ścięgien i stawów, złamań i zapaleń kości oraz stawów rzekomych. ${ }^{1,3}$ PRP jest skuteczną metodą terapeutyczną $\mathrm{w}$ leczeniu tendinopatii. W badaniu, przeprowadzonym przez de Vos i wsp., porównywano efekty iniekcji do ścięgna Achillesa: PRP i soli fizjologicznej. 1,30 Natomiast Vetrano i wsp. wykazali przewagę PRP nad terapią metodą ESWT (extracorporeal shock wave therapy - terapię radialnymi falami uderzeniowymi) u chorych $\mathrm{z}$ tendinopatią okolicy rzepki. ${ }^{1,31}$

Anitua i wsp. również wykazali pozytywne efekty koncentratów płytkowych na tanocyty, udowadniając ich wpływ na namnażanie tych komórek oraz uwalnianie aktywatorów angiogenezy. ${ }^{32}$ Franchini i wsp. stosowali koncentrat krwinek płytkowych w złamaniach i zapaleniach, rekonstrukcjach kostnych przy protezoplastykach stawów biodrowych, stawach rzekomych, ponad to w dysplazji włóknistej. ${ }^{33}$ Bibbo i wsp. prowadzili badania w grupie osób poddawanych artrodezie stawu skokowego. ${ }^{34}$ Kolejne zastosowania obejmują rekonstrukcję stawu kolanowego i poprawę regeneracji przeszczepów więzadła krzyżowego. ${ }^{4}$ Podejmowane są także próby wykorzystania osocza bogatopłytkowego w leczeniu uszkodzeń powierzchni stawowych, a także reumatoidalnego zapalenia stawów. Badania mają na celu ocenę przyspieszenia gojenia chrząstki stawowej po podaniu PRP. ${ }^{4}$ 
concentrations lower or higher than 1.5 million thrombocytes $/ \mu$ inhibited the angiogenic potential in human endothelial cells. ${ }^{36}$ The anticoagulant is also significant. Jensen et al. used EDTA in their studies to observe the prolonged healing time of tissues. ${ }^{8}$

Concerns regarding the safety of the PRP were raised. The use of bovine thrombin as an activator of the coagulation process aroused concern about the transfer of Cruetzfeld-Jacob disease. ${ }^{37}$

Doubts in dental implantology were presented in the works of Froum et al. and Shanaman et al., in which the ability of PRP to assist osteoinduction was not demonstrated. ${ }^{38,39}$ To better understand the limitations and advantages in clinical phases associated with the use of PRP far more reliable research is needed.

\section{Summary}

Therapy with autologous platelet-rich plasma is regarded as a cure of the future. Due to the simplicity and low cost of acquisition, as well as the lack of risk of transmission of infectious diseases, it demonstrates increasing popularity in many areas of medicine. However, due to the lack of validated methods of control and optimisation of factors such as, for example, composition, concentration, quality and time of operation of growth factors, PRP is still an unrecognised area. It is clear from the currently available literature that there is a large variability in research design, clinical measurements and obtained results. New randomised clinical trials are needed to establish indications, confirm efficacy and safety of PRP use.

\section{Ograniczenia metody}

Liczne badania dokumentują pozytywne skutki stosowania PRP. Jednakże istnieją publikacje, w których stwierdzono, iż nie przynosi żadnych korzyści lub ma niewielki wpływ. Poziom dowodów z dostępnych opublikowanych danych jest niski. Ciągle nie ma podwójnie ślepych, randomizowanych badań przeprowadzonych na dużej grupie badawczej. Opracowano wiele protokołów, urządzeń i wirówek do pozyskiwania różnych preparatów krwiopochodnych. Niestety wszystkie kryją się pod jedną nazwą osocza bogatopłytkowego. Ehrenfest i wsp. sklasyfikowali i opisali koncentraty płytek krwi w zależności od ilości leukocytów i trombiny. ${ }^{35} \mathrm{~W}$ związku z tym lekarze stosujący PRP powinni zachować szczególną ostrożność.

Istotne okazało się odpowiednie stężenie płytek krwi. Giusti i wsp. wykazali, że niższe lub wyższe stężenia, niż 1,5 miliona trombocytów/ $\mu 1$ hamowało potencjał angiogenny w ludzkich komórkach śródbłonka. ${ }^{36}$ Znaczący jest również antykoagulant, Jensen i wsp. w swoich badaniach zastosowali EDTA i zaobserwowali wydłużenie czasu gojenia się tkanek. ${ }^{8}$

Zgłaszano zastrzeżenia dotyczące bezpieczeństwa PRP. Stosowanie bydlęcej trombiny jako aktywatora procesu krzepnięcia budziło niepokój przeniesienia choroby CruetzfeldaJacoba. ${ }^{37}$ Wątpliwości w implantologii stomatologicznej pokazały prace Froum 'a i wsp. oraz Shanaman i wsp., w których nie wykazano zdolności PRP do osteoindukcji. ${ }^{38,39}$ Aby lepiej poznać ograniczenia i korzyści w fazach klinicznych związanych z zastosowaniem PRP potrzeba większej ilości rzetelnych badań.

\section{Podsumowanie}

Terapia autologicznym osoczem bogatopłytkowym jest uznawana za skuteczną motodę regeneracyjną. Ze względu na prostotę i niski koszt pozyskania, a także brak ryzyka 
transmisji chorób zakaźnych cieszy się rosnąca popularnością $\mathrm{w}$ wielu dziedzinach medycyny. Jednak ze względu na brak walidowanych metod kontroli oraz optymalizacji czynników, takich jak: skład, stężenie, jakość i czas działania czynników wzrostu, PRP ciągle stanowi nie w pełni poznany obszar. Z aktualnie dostępnej literatury jasno wynika, że istnieje duża zmienność w projektowaniu badań, pomiarach klinicznych oraz uzyskiwanych wynikach. Potrzebne są nowe randomizowane badania kliniczne, aby ustalić wskazania, potwierdzić skuteczność oraz bezpieczeństwo stosowania PRP.

\section{References / Piśmiennictwo}

1. Gołos A, Treliński J: Kliniczne zastosowanie osocza bogatopłytkowego. Hematologia 2014; 5(3): 252-259.

2. Cieślik T: Czynniki wzrostu zawarte w osoczu bogatopłytkowym jako autogennym materiale stymulującym procesy gojenia tkanki kostnej Growth factors in the platelet-rich plasma as autogenic material which stimulates bone healing processes. J Stomatol 2006; 7: 510517.

3. Aleksiewicz R, Starczewska I, Kostrzewski M: Autologiczne osocze bogatopłytkowe - możliwości zastosowania klinicznego. Med Weter 2015; 71(5): 276-280.

4. Chomicki-Bindas $P$, Zakrzewski $P$, Pomianowski $S$ : Koncentraty płytkowe zawierające czynniki wzrostu, jako nowa, obiecująca technika poprawy gojenia kości i tkanek miękkich w chirurgii ortopedycznej wprowadzenie do zagadnienia. Postępy Nauk Med 2010; 2: 153-157.

5. Matthews-Brzozowska T, Krzyżanowska A, Lichaj M: Revitalization of facial skin based on preparations of patient own blood. J Med Sci 2017; 86(2): 173-176.

6. Przadka P, Kiełbowicz Z, Skrzypczak P: Autogenne osocze bogatopłytkowe - rodzaje, sposoby aktywacji i zastosowanie. Med Weter 2016; 72(7): 403-407.

7. Ciślik-Bielecka A, Bielecki T, Gaździk T, Cieślik T: Czynniki wzrostu zawarte w osoczu bogatopłytkowym jako autogennym ma- teriale stymulującym procesy gojenia tkanki kostnej. Czas Stomatol 2006; 7: 22-25.

8. Jensen B, Rahbek $O$, Overgaard $S$, Soballe $K$ : Platelet rich plasma and fresh frozen allograft as enhancement of implant fixation. An experimental study in dogs. J Orthop Res 2004; 22: 653-658.

9. Appel T, Pötzsch B, Müller J: Comparison of three different preparations of platelet concentrates for growth factor enrichment. Clin Oral Impl Res 2002; 13: 522-528.

10. Andia I, Sanchez M, Maffulli N: Joint pathology and platelet-rich plasma therapies. Expert Opin Biol Ther 2012; 12: 7-22.

11. Drago L, Bortolin M, Vassena C, Taschieri $S$, Fabbro $M$ : Antimicrobial activity of pure platelet-rich plasma against microorganisms isolated from oral cavity. BMC Microbiol 2013; 13: 1-5.

12. El-Sharkawy H, Kantarci A, Deady J, Hasturk H, Liu H, Alshahat M, Van Dyke TE: PlateletRich Plasma: Growth Factors and Pro- and Anti-Inflammatory Properties. J Periodontol 2007; 78(4): 661-669.

13. Mishra A, Pavelko T: Treatment of chronic elbow tendinosis with buffered platelet-rich plasma. Am J Sports Med 2006; 34: 17741778.

14. Ferrari M, Zia S, Valbonesi M, Henriquet $F$, Venere G, Spagnolo S, Grasso MA, Panzani I: A new technique for hemodilution, preparation of autologous platelet-rich plasma 
and intraoperative blood salvage in cardiac surgery. Int J Artif Organs 1987; 10: 47-50.

15. Clendenen N, Ginde A: Efficacy of plateletrich plasma of conservative treatment in ortopeadics. Blood transfus 2018; 16: 473474.

16. Ameer LAA, Raheem ZJ, Abdulrazaq SS, Ali $B G$, Nasser MM, Khairi AWA: Przeciwzapalne działanie osocza bogatopłytkowego w kieszonce przyzębnej. Eur J Dent 2018; 12(4): 528-531.

17. Rattanasuwan K, Rassameemasmaung S, Kiattavorncharoen S, Sirikulsathean A, Thorsuwan J, Wongsankakorn W: Platelet-rich plasma stimulated proliferation, migration, and attachment of cultured periodontal ligament cells. Eur J Dent 2018; 4(12): 469474.

18. Murray PE: Platelet-Rich Plasma and Platelet-Rich Fibrin Can Induce Apical Closure More Frequently Than Blood-Clot Revascularization for the Regeneration of Immature Permanent Teeth: A Meta-Analysis of Clinical Efficacy. Front Bioeng Biotechnol 2018; 6.

19. Simonpieri A, Del Corso $M$, Vervelle A, Jimbo $R$, Inchingolo $F$, Sammartino $G$, Dohan Ehrenfest DM: Current knowledge and perspectives for the use of platelet-rich plasma (PRP) and platelet-rich fibrin (PRF) in oral and maxillofacial surgery part 2: bone graft, implant and reconstructive surgery. Curr. Pharm.Biotechnol 2012; 13(7): 12311256.

20. Chorażewska M, Piech P, Pietrak J, Koziot $M$ : The use of platelet-rich plasma in antyaging therapy. rnal Educ Heal Sport 2017; 7(11): 162-175.

21. Cervelli V, Gentile P, Scioli MG, Grimaldi $M$, Casciani CU, Spagnoli LG, Orlandi A: Application of platelet - rich plasma in plastic surgery: clinical and in vitro evaluation. Tissue Eng. Part C Methods 2009; 15: 625634.
22. Alam M, Hughart R, Champlain A: Effect of Platelet-Rich Plasma Injection for Rejuvenation of Photoaged Facial Skin: A Randomized Clinical Trial. JAMA Dermatology 2018; 1; 154(12): 1447-1452.

23. Redaelli A, Romano D, Marcianó A: Face and neck revitalization with platelet-rich plasma (PRP): Clinical outcome in a series of 23 consecutively treated patients. Drugs Dermatology 2010; 9: 466-472.

24. Szpringer A, Szpringer E: Zastosowanie osocza bogatopłytkowego w medycynie estetycznej. Aesthetica 2015; 8(3/4): 12-19.

25. El-Domyati M, Abdel-Wahab H, Hossam A: Microneedling combined with platelet-rich plasma or trichloroacetic acid peeling for management of acne scarring: A split-face clinical and histologic comparison. J Cosmet Dermatol 2018; (17): 73-83.

26. Willemsen JCN, Lei B van der, Vermeulen KM, Stevens HPJD: The Effects of PlateletRich Plasma on Recovery Time and Aesthetic Outcome in Facial Rejuvenation: Preliminary Retrospective Observations. Aesthetic Plast Surg 2014; 38(5): 1057-1063.

27. Hirase T, Ruff E, Surani S, Ratnani I: Topical application of platelet-rich plasma for diabetic foot ulcers: A systematic review. World J Diabetes 2018; 10(9): 172-179.

28. McAleer JP, Kaplan E, Persich G: Efficacy of concentrated autologous platelet-derived growth factors in chronic lower-extremity wounds. J Am Podiatr Med Assoc 2006; 96: 482-488.

29. Butt G, Hussain I, Ahmed F, Choudhery M: Skuteczność osocza bogatopłytkowego u pacjentów z łysieniem androgenowym. Cosmet Dermatology. 2018.

30. de Vos RJ, Weir A, van Schie HT, BiermaZeinstra SM, Verhaar JA, Weinans $H$, Tol JL: Platelet-rich plasma injection for chronic Achilles tendinopathy: a randomized controlled trial. JAMA 2010; 303: 144-149.

31. Fanning J, Murrain L, Flora R, Hutchings 
T, Johnson JM, Fenton $B W$ : Phase I/II prospective trial of autologous platelet tissue graft in gynecologic surgery. J Minim Invasive Gynecol 2007; 14: 633-637.

32. Anitua E, Andia J, Sánchez M, Azofra J, del Mar Zalduendo $M$, de la Fuente $M$, Nurden $P$, Nurden AT: Autologous prepariations rich in growth factors promote proliferation and induce VEGF and HGF production by human tendon cells in culture. J Ortop Res 2005; 23 : 281-286.

33. Franchini $M$, Dupplicato P, Ferro I, De $G M$, Aldegheri $R$ : Efficacy of platelet gel in reconstructive bone surgery. Orthopedics 2005; 28(2): 161-163.

34. Bibbo C, Bono CM, Lin SS: Union rates using autologous platelet concentrate alone and with bone graft in high-risk foot and ankle surgery patients. J Surg Orthop Adv 2005; 14(1): 1722.

35. Ehrenfest D, Rasmusson L, Albrektsson $T$ : Classification of platelet concentrates: from pure platelet-rich plasma (P-PRP) to leucocyte- and platelet-rich fibrin (L-PRF).
Trends Biotechnol 2009; 27: 158-167.

36. Giusti I, Rughetti A, D’Ascenzo S, Millimaggi D, Pavan A, Dell'Orso L, Dolo V: Identification of an optimal concentration of platelet gel for promoting angiogenesis in human endothelial cells. Transfusion 2009; 49(4): 771-778.

37. Kumaran MS: Platelet-rich plasma in dermatology: Boon or a bane? Indian J Dermatol Venereol Leprol 2014; 80(1): 5-14.

38. Froum SJ, Wallac SS, Tarnow DP, Cho S-C: Effect of Platelet-Rich Plasma on Bone Growth and Osseointegration in Human Maxillary Sinus Grafts: Three Bilateral Case Reports. Int J Periodontics Restorative Dent 2002; 22(1): 45-53.

39. Shanaman $R$, Danesh-Meyer MJ: Localized ridge augmentation using GBR and plateletrich plasma: case reports. Int J Periodont Restor Dent 2001; 21(4): 345-355.

Zaakceptowano do druku: 13.06.2019 r.

Adres autorów: 41-902 Bytom, pl. Akademicki 17 siedziba zamiejscowa 41-800 Zabrze, pl. Traugutta 2. C) Zarząd Główny PTS 2019. 